\section{THE SUK PEOPLES.}

MR. BEECH has written an extremely interesting $\mathrm{I}$ book, the possession of which will be a necessity to every anthropologist and student of African languages; and the introduction to this work by Sir Charles Eliot is not a few vapid pages of commendatory remarks signed by a notable name, but an essential portion of the book itself.

Mr. Beech commences his work by a description of the Sük people, and a sketch of their affinities with the surrounding peoples. He comes to the conclusion which was first published by the writer of this review in I902, that the so-called Sük peoples are really an assemblage of very diverse Negro and Negroid trpes whom the force of circumstances has driven into something like tribal cohesion in that picturesque country of deep ravines, high plateaux, volcanic peaks, and hot plains, between Lakes Rudolf and Baringo on the east, and the Elgon and Nandi plateaux on the west. Mr. Beech thinks that the traditions of the old men show that there were (in the main) two original tribes living in the western part of the Sūk country (the Elgeyo escarpment), the names of which were Chuk or Chol (the origin of the present name, which is a Masai corruption popularised by Joseph Thomson), and Seker; and that fugitives and adventurers from various surrounding districts entered the Sük country, and intermarried with the two original tribes. "Every type is represented, from the tall, handsome Hamite, with almost perfect features, to the short, dwarf-like pygmy, with spread nose and bolting eyes."

The author is inclined to think that this last-named type characterised both the original Chuk and Seker. Elsewhere in the book, in connection with the illustrations, Mr. Beech refers to a "Bushmanlike" type. Some of the first explorers who wrote on the subject of the Sük people (including the reviewer) were apt to speak of the Bushmanlike type of $\mathrm{Pyg} \mathrm{my}$ amongst them and amongst the neighbouring Andorobo (the Andorobo, be it observed, speak a language which is related to that of the Sük, the Nandi, \&c.). It is, we believe, the case that one or two trustworthy observers have noted types of physique amongst

the Andorobo which offer a slight resemblance to the Bushman, but it now seems to be clear that the Pygmy type of Sük, which also reappears amongst the Bantu tribes of Mount Elgon, as well as farther west in eastern Uganda, is decidedly not of Bushman affinities, but, on the contrary, obviously connected with the Congo Pygmy. This would seem to be the case with

1 “'The Suk: their Language and Folklere.' By M. W. H. Beech. With an introduction by Sir Charles Eliot. Pp, xxiv $+{ }_{5}+3$ maps +24 plates. (Oxford: Clarendon Press, rgri.) Price 12s. 6d, net. the dwarf tribes of southern Ethiopia first seen by the missionary Krapf, and of the Red Bongo, and other dwarf peoples of the Egyptian Sudan. There is no marked steatopygia amongst the Pygmy Sük or any of the dwarf races just mentioned. In other anatomical features connected with the external genitalia of men and women (which it is not necessary to specify here, but which are clearly illustrated in Dr. Péringuey's work on the Stone Age in South Africa), they are almost the opposite pole amongst Negro races to the Bushman.

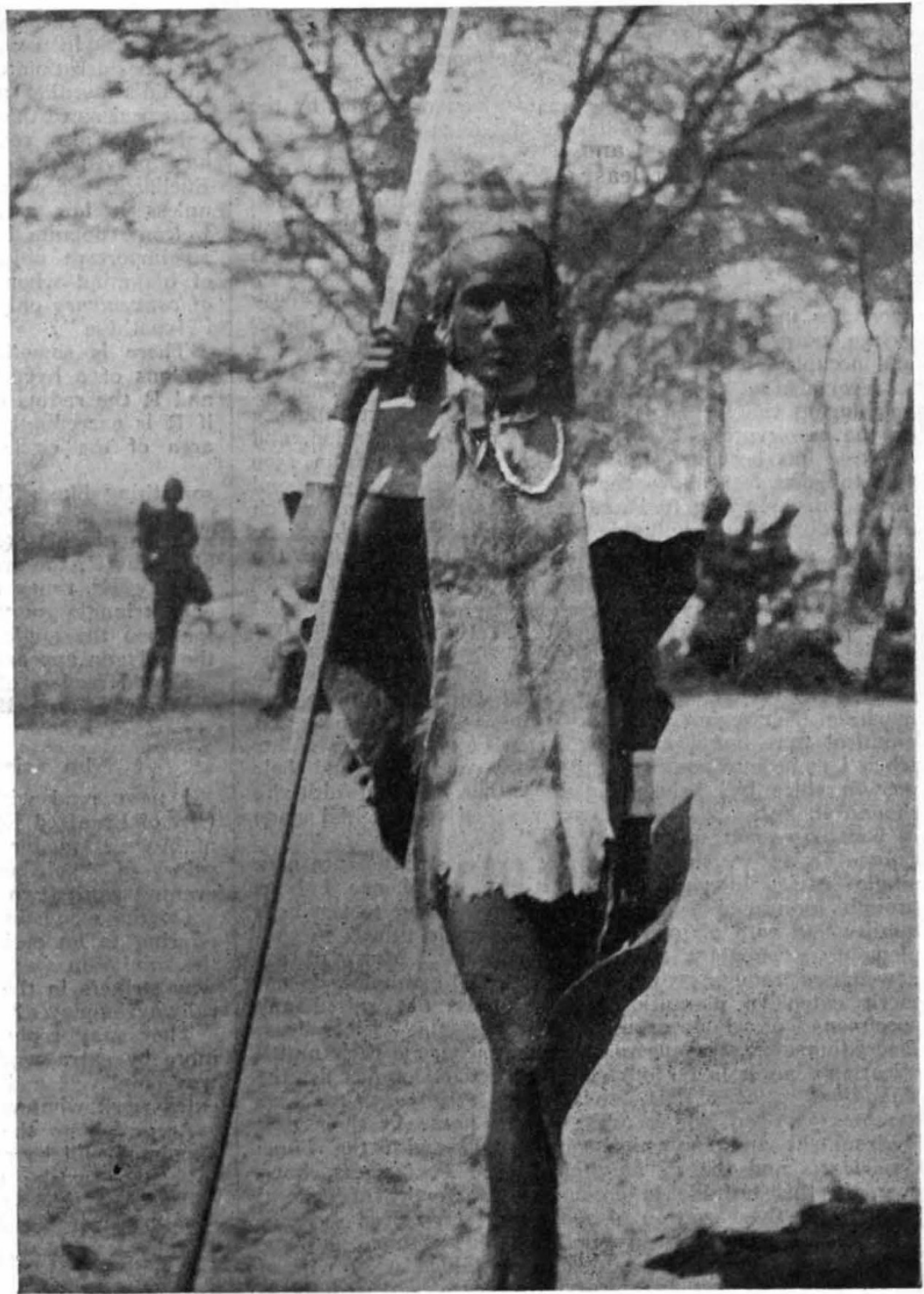

Pastoral Suk (type $x$ ). From "The Suk : their Language and Folklore."

The one or two illustrations of Pygmy types of Sük in Mr. Beech's book are of value in emphasising this fact (the non-Bushman likeness of the Pygmy Sük), the more so as they are taken from nude figures.

As regards the Sük language, Mr. Beech comes to conclusions which seem to the reviewer to be thoroughly sound. He recognises the great affinity between Sük and Nandi (to which we would venture to add the Ndorobo, Sotik, and other "Nandi" languages, and shows that the Turkana-that giant race of Lake 
Rudolf-though it has so many affinities with the Sük in regard to head-dress, costume, and customs, is far more nearly related to the Masai-Bari group in language. In fact, this book supplies a good deal of evidence which would show that Nandi and Sük and the allied languages, though they must be classed in the same group with the Nilotic and Masai tongues, nevertheless stand very much apart from their congeners, and no doubt include a considerable element of pre-existing tongues quite unrelated to those sexdenoting languages which sprang into existence in the Nile Valley, influenced, it may be, in a slight degree by the Hamitic tongues of invading White men.

In a general way it may be said that the Masai-Bari-Turliana section of these Nilotic tongues is sex. denoting, and that the other groups (Shiluk-Dinka-Jaluo and NandiSük) are not; or, at least, that the principle of indicating the female sex in pronouns and prefixes has very much weakened. In reference to this argument may be mentioned the tendency on the part of certain German and English writers on African languages in recent times to persist in classing the Nilotic languages or members of the Nilotic family as "Hamitic," because they, like the totally unrelated Bongo language group of the western Egyptian Sudan, are sex-denoting. This idea in the syntax may have been inspired originally by invading Caucasians of Hamitic speech, but the result is attained, not-as in the case of Hausa and Musga-by the deliberate adoption of Hamitic feminine particles, but by the use of Negro vocables common also to the Bantu languages to indicate sex, such as ol or lu for the masculine (Bantu, lume), and na or nya (a word originally meaning "mother") for the feminine.

A great many interesting points in connection with African philology are indicated or are explained in this valuable little book, which may be finally commended for its lightness in the hand and for the mass of first-rate information which is packed into a small compass. H. H. JoHnston.

WESTLAND-A NEW ZEALAND PROVINCE. ${ }^{1}$

WESTLAND is the province on the western coast of the South Island of New Zealand. Its name brings back a vision of a land covered by forests of tropical luxuriance, rising from a blue sea fringed by a white line of surf to blue mountains capped with fields of snow, of clean glaciers flowing steeply down into glades of tree ferns, and of a succession of pictures so varied and all so perfect in composition that we regard Westland as the most beautiful country it has been our privilege to see.

Miss M. Moreland tells in this volume the story of a ride through this district; and though she gives singularly little information, her book conveys a pleasing

1 "Through South Westland: a Journey to the Haast and Mount Aspiring, New Zealand." By A. Maud Moreland. Pp. xviiit221. (Loudon: Witherby and Co., rgrr.) Price $7 s .6 d$. net. impression of her keen enjoyment of the scenery, and her enthusiastic admiration of the people. She dedicates her book to the New Zealanders who taught her to love their land. She rode from the Canterbury Plains across the Southern Alps to the western coast, and then down Westland, and back by the southern road to the eastern side of the New Zealand Alps. The book is illustrated by forty-eight excellent photographs and two maps. The author is not a geographer, and it was apparently only the special charm of the New Zealand flora that has roused her interest in botany; she was startled to find that the New Zealand lily is a tree, the Cordyline, that the pines equally exceed the

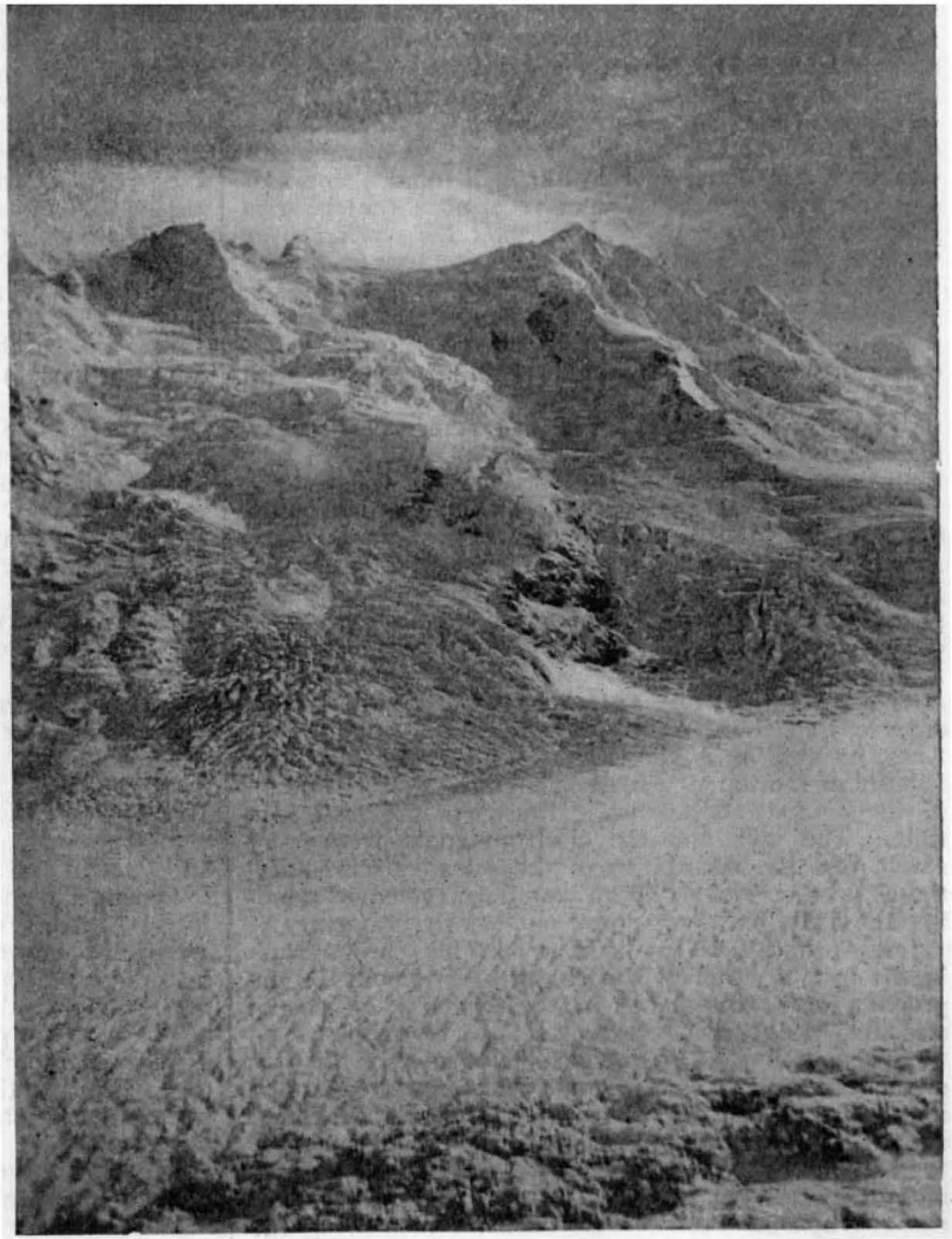

The Minarets : from the Tasman Glacier. From " Through South Westland."

stunted pines of Scotiand, and that the flax, the name of which she always spells Formium, has a much longer and stronger fibre than the European flax. She expresses her great indebtedness for her knowledge of the plants to the work of Laing and Blackwell.

While in Westland she visited a survey camp, and one of its members talked to her so enthusiastically about the silver cone of "Mount Aspiring" that she resolved to visit it, and after sundry misadventures reached the valley at its foot. She did not climb it. The first ascent was reserved for Captain Head. "For us," she says, "it is enough to have seen the great Silver Cone against the blue; we come no more." This 